\section{Michał Wojciechowski}

Uniwersytet Warmińsko-Mazurski, Olsztyn

m.wojciechowski@uwm.edu.pl

DOI: http://dx.doi.org/10.12775/BPTh.2016.039

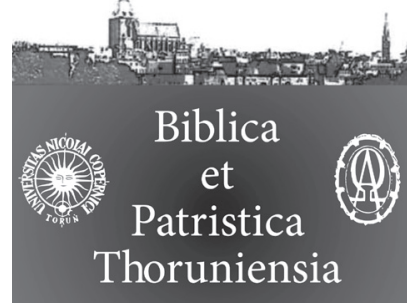

9 (2016) 4: 151-163

ISSN (print) 1689-5150

ISSN (online) 2450-7059

\title{
Słabe punkty polskiego tłumaczenia Ewangelii w Biblii Tysiąclecia
}

\section{Weak points of the Polish translation of the Gospels in the "Millenium Bible"}

Streszczenie. Planowane jest szóste wydanie Biblii Tysiąclecia, najpopularniejszego polskiego przekładu Pisma Świętego. Czy wobec jej słabości nie byłoby lepiej tego tłumaczenia zastąpić nowym? Część sporów o prawidłowy kształt tłumaczeń wynika wprawdzie z różnych koncepcji tłumaczenia. Wiadomo też, że nie każdy termin można adekwatnie przełożyć. Dopuszczając różne rozwiązania, trzeba jednak pytać, czy przekład nie zawiera błędów oraz przekłamań wynikłych z założeń interpretacyjnych. W Ewangeliach z Biblii Tysiąclecia można stwierdzić nadużywanie wyrażeń uroczystych, nieadekwatnych względem ducha oryginału. Zdarzają się też zniekształcenia wynikłe z chęci wzmocnienia wymowy teologicznej tekstu (Jezus przed sędziami; opętania), uczynienia go bardziej rygorystycznym (moralność płciowa, pacyfizm), albo przeciwnie mniej dobitnym (gniew Jezusa). Zdarza się nietrafny dobór słowa polskiego, dodawanie słów nieobecnych w oryginale, błędy ze sfery krytyki tekstu. Interesujące przykłady znajdziemy także w innych księgach biblijnych.

Abstract. The sixth edition of "Millenium Bible", the leading Polish Bible translation, is planned. Considering its weaknesses, it would be perhaps better to replace it with a new translation. However, some conflicts concerning the correct shape of biblical translations result from the different ideas about translating. Not every word can be satisfactorily translated. Even accepting various solutions, we should ask whether the translation is free of errors and of false renderings resulting from some presuppositions. In the Gospels from the Polish "Millenium Bible" we may find the excessive use of solemn expressions, not corresponding to the spirit of the original text. The are some deformations resulting from the opinions of translators. They strengthen the theological message of the texts (Jesus before his judges; possessions), make it morally more rigorous (sexual ethics, pacifism), or less dynamic (the anger of Jesus). There are inadequate translations of single words, adding words absent in the original, mistakes concerning textual criticism. Interesting examples can be found in other biblical books.

Słowa klucze: Biblia Tysiąclecia; polskie przekłady biblijne; Ewangelie.

Keywords: Millenium Bible; Polish Bible translations; Gospels. 
Tiedawno zapowiedziana została nowa rewizja najpopularniejszego obecnie polskiego przekładu biblijnego, a znanego jako Biblia Tysiąclecia $(\mathrm{BT})^{1}$. Ma to być już szóste jej wydanie. 7 czerwca 2016 Konferencja Episkopatu Polski powołała dla przygotowania go nowy komitet redakcyjny ${ }^{2}$. Redaktor naczelny wydań dotychczasowych, O. Augustyna Jankowski OSB, zmarł bowiem w 2005 roku. Koncepcja i zakres planowanej rewizji nie są jeszcze znane. Na pewno jednak jest to okazja do krytycznej oceny tego przekładu.

Był on już wielokrotnie zmieniany, ale nigdy gruntowniej. Liczne zmiany nastąpiły między 1 a 2 wydaniem. W wydaniu 3 przystosowano język do użytku liturgicznego (np. imię Jahwe na życzenie kard. Wyszyńskiego zastąpiono, z małymi wyjątkami, słowem „Pan”) ${ }^{3}$. Wydanie 4 powtarza wydanie 3 (wydania samego Nowego Testamentu, liczniejsze, też bywają identyczne). W wydaniu 5 poprawiono dalsze mniejsze usterki oraz ulepszono wstępy do ksiąg. Ilościowo tych poprawek było w sumie bardzo dużo, ale na ogół chodziło w nich o drobiazgi: korektę językową, usterki edytorskie, przypisy itd.

BT doczekała się też wielu omówień, w tym obszernych, zarówno krytycznych, jak umiarkowanych i przychylnych. Znana była krytyczna broszura ks. Eugeniusza Dąbrowskiego ${ }^{4}$. W obronie BT, choć nie apologetycznie, wypowiadał się m.in. ks. Janusz Frankowski ${ }^{5}$. Potem traktowano BT jako tekst zastany i podstawowy ${ }^{6}$. Liczni bibliści przesyłali swoje uwagi bezpośrednio do komitetu redakcyjnego ${ }^{7}$.

Część zgłoszonych uwag została w kolejnych wydaniach uwzględniona. Mimo to, jak zobaczymy, BT nadal może budzić rozmaite zastrzeżenia, także w swoim kształcie obecnym. Jak go oceniać? Przed przedstawieniem obserwacji szczegółowych potrzebne są pewne zastrzeżenia.

1 Pismo Święte Starego i Nowego Testamentu, Pallottinum, Poznań, wyd. 1 1965, wyd. 2 1971, wyd. 3 1980, wyd. 4 1983, wyd. 51999.

2 W jej skład weszli księża bibliści: Henryk Witczyk (przewodniczący), Waldemar Chrostowski (ST), Arnold Zawadzki (ST), Andrzej Geniusz CR (NT), Marcin Kowalski (NT).

Unika się przez to brzmienia niezwykłego dla słuchaczy, ale zarazem niweluje się różnicę między imionami Jahwe i Adonai. Najlepsze rozwiązanie to wzorowane na przekładach zachodnich oddanie Adonai przez „Pan”, a Jahwe przez „PAN” (tak to czyni przekład paulistów).

4 E. Dąbrowski, Nowy polski.

5 J. Frankowski, Dlaczego, oraz Biblia. Por. też S. Mędala, Biblia.

6 Por. J. Chmiel, Textus.

7 Sądząc z moich własnych doświadczeń, były one wykorzystywane, ale bardzo ułamkowo. 
Nie ma przekładu bez błędów; kto tłumaczył, wie o tym. Należy je więc stale poprawiać. Wiele krytyk pod adresem przekładów nie ma jednak należytych podstaw. Przede wszystkim dlatego, że przy tłumaczeniu trzeba bowiem zawsze podjąć pewne decyzje co do jego koncepcji. Zwolennik innego typu tłumaczenia będzie wtedy niezadowolony. Rozmaite rozwiązania translatorskie, w większej czy mniejszej skali, okazują się nie do pogodzenia.

Wspomnę tu rozbieżne możliwości co do koncepcji przekładu. Po pierwsze, czy tłumaczymy bardziej werbalnie, słowo w słowo, czy też ad sensum, szukając wyrażeń i zdań, które niosą to samo znaczenie co oryginał, nie powtarzając jego słów. W tym przypadku tłumacze Biblii nieraz mówią o „ekwiwalencji dynamicznej”. Obie metody mają wady. Przekład dosłowny nieraz brzmi myląco lub niejasno i wymaga dodatkowych objaśnień. Przekład ad sensum wpada w parafrazę i zawiera interpretacje, nieraz nieświadome. Możliwe są też rozwiązania pośrednie.

Następnie, można używać brzmiącego uroczyście języka tradycyjnego, bliskiego dawniejszym przekładom biblijnym, albo też języka religijnego w jego formie obecnej. Język współczesny też może być bardziej literacki albo zwyczajniejszy. Możliwe są świadome eksperymenty, polegającego na odejściu od utartej terminologii ${ }^{8}$ albo na użyciu języka potocznego i ułatwionego.

Każdy przekład boryka się z tym, że wiele słów ma więcej znaczeń. Czy nefesz/psyche to w danym miejscu dusza, życie, czy osoba? Czy serce to wnętrze, myślenie, charakter? Inne przykłady: ojcowie czy przodkowie? Żydzi czy Judejczycy? Szczęśliwy czy błogosławiony? Wszystkie te przykłady były szeroko dyskutowane. Dylematów takich nie da się bowiem do końca rozstrzygnąć9.

W przekładach biblijnych problemem bywają poziomy znaczenia. To samo pojęcie może mieć inne zabarwienie po hebrajsku, po grecku i w późniejszym języku kościelnym. Po hebrajsku nawrócenie, czyli zmiana kierunku i postępowania, po grecku metanoja, czyli przemiana duchowa i umysłowa, w Kościele pokuta.

Często pojawia się napięcie między sensem ogólnym a religijnym: zanurzenie czy chrzest; posłaniec czy anioł? Żaden z tych terminów nie jest całkiem adekwatny. W ostatnim przypadku najtrafniejsze wydaje się przestarzałe słowo

8 Nie praktykuje się tego, ale można by, tłumacząc etymologicznie, zastąpić proroka przez rzecznika, apostoła przez wysłannika, Kościół przez zgromadzenie, zbawienie przez ratunek, wiarę przez wierność itd. Przekład taki brzmiałby niezwykle, ale byłby świeższy i przybliżałby do oryginału.

9 Czasem obiekt z tekstu nie ma ustalonej polskiej nazwy: podwyższenie, na którym urzędował sędzia, gr. bema, ma w przekładach z dziesięć różnych odpowiedników. 
„Zwiastun”. Albo: odpoczynek czy szabat? Dekalog mówi: „pamiętaj, byś świętował dzień odpoczynku”, raczej niż „dzień szabatu”.

Od każdego przekładu można i trzeba jednak żądać, by unikał błędów, jak również przekłamań wynikłych z uprzedzeń tłumacza, albo, żeby nie ujmować tego tak trywialnie, $\mathrm{z}$ koncepcji interpretacyjnych. Przekład powinien być generalnie adekwatny względem treści i stylu oryginału, konsekwentny, powinien też odpowiadać celowi, jakiemu ma służyć. Natomiast nie należy opierać oceny na własnych upodobaniach co do typu przekładu, choć to nie do końca jest możliwe.

Przejdźmy zatem do Biblii Tysiąclecia. Co można tu wstępnie zauważyć? Jest to raczej przekład typu dosłownego niż swobodny i literacki. Jak na pracę zbiorową wydaje się jako tako jednolity metodycznie (inaczej niż na przykład Biblia Poznańska, gdzie przekłady dość dosłowne sąsiadują ze swobodnymi). Preferuje utarty polski język religijny, ale na ogół rezygnuje z archaizmów. Nie przejawia większej dbałości o piękno językowe (nie czuję się kompetentny w kwestii oceny polszczyzny BT, wiadomo jednak, że bywała ona przedmiotem krytyk $)^{10}$. Tłumaczy to geneza tego tłumaczenia, planowanego jako praca naukowa, z drugiej nie porzucająca polskiego języka biblijnego. Późniejsze upowszechnienie tego przekładu nie było z góry zamierzone i mimo wysiłków nie całkiem go dostosowano do potrzeb szerszego czytelnika. Nadal wymaga on też wielu krytyk szczegółowych, co przedstawię na wybranych testach z Ewangelii.

\section{Nieuzasadniony styl uroczysty}

W zasadzie BT archaizacji unika, ale nie jest pod tym względem konsekwentna. Styl uroczysty i przestarzały się w niej trafia, i to tam, gdzie oryginał wcale się nim nie cechuje. Przez język podniosły przekład wplata zatem interpretację do tekstu. Poniżej przedstawię przykłady. Podniosłość bywa efektem kopiowania szyku słów z oryginału, np. umieszczania zaimków po rzeczowniku określanym. To zdarza się często w przekładzie Ewangelii św. Jana.

Jezus spożywa zamiast jeść, chociaż $\mathrm{w}$ oryginale greckim mamy prawie zawsze formy od zwyczajnego esthio. Powinno być „poborcy”, a nie „celnicy”. Gr. fyle to nie „pokolenie”, lecz „plemię” bądź „ród”. Powinno być „chrzcił”, a nie „udzielał chrztu” - tu pojawia się język urzędowy (np. J 10,40). Analogicznie

10 Po rewizjach jest na pewno sporo lepsza niż w pierwszych wydaniach, ale można nadal odnieść wrażenie przeciętności stylu. Np. o ile gładziej czyta się listy Pawłowe w przekładzie Edycji Świętego Pawła niż w BT! Muszę jednak zaznaczyć, że przekład paulistów wydaje mi się w wielu miejscach zbyt swobodny. 
„odmówił błogosławieństwo” to po prostu „pobłogosławił” (Mt 14,19; 26,26). Nikt dziś w języku codziennym nie mówi o cudzołóstwie, chyba że z ironią: lepiej byłoby „zdrada małżeńska”. No i „sycera”, słowo archaiczne, niezrozumiałe i zbędne, gdyż chodzi zasadniczo o piwo (Łk 1,15 i ST: napój alkoholowy $\mathrm{z}$ jęczmienia, może i z innych płodów roli).

Ważny przykład to utarte po polsku co najmniej od Biblii Wujka określanie Jezusa jako Syna Człowieczego, dużymi literami. Sugeruje to dzisiaj wzniosły, tajemniczy tytuł. Tymczasem po hebrajsku, aramejsku i w biblijnej grece, a zresztą i w dawnej polszczyźnie, zwrot ten oznacza tyle, co „syn ludzki”. Określenie omawiane mocno akcentuje człowieczeństwo Jezusa, co przekłady polskie przysłaniają. Czasami, jak w zdaniu „syn ludzki jest także panem szabatu” (Mk 2,28 par.), nawet nie dotyczy Jezusa. Owszem, Jezus mówiąc często w ten sposób o sobie, czynił aluzję do kogoś podobnego do człowieka, postaci mesjańskiej z Księgi Daniela. Była to jednak tylko aluzja. Miano to stosował, zapewne rozmyślnie, w sposób wieloznaczny. Dopiero przed sanhedrynem do proroctwa Daniela odwołał się wyraźnie (Mk 14,62 par.).

Najszkodliwsze jest jednak to, że zaimki, które odnoszą się do Osób Boskich, Jezusa jako człowieka i jego matki pisane są w BT z dużej litery. Jest to jaskrawa sprzeczność z oryginałem, gdzie zaimki te są niesamodzielne i przeważnie nawet nie akcentowane. Dość często można by je po prostu pominąć. Raczej „czcij ojca i matkę” niż „czcij ojca swego i matkę swoją”.

Nadmiar dużych liter wcale nie nawiązuje do tradycji. Jest to koncepcja redaktorów BT, gdyż przekłady wcześniejsze ich nie nadużywały. Przeniesiono tę manierę z niektórych tekstów liturgicznych, wmawiając wszystkim, że taka powinna być norma. Tymczasem oddawanie czci Panu Jezusowi przez sztuczną ortografię wydaje się mocno powierzchowne.

Dalsze przekłady poszły niestety za tym, choć zostawiając małą literę przy pierwszej osobie. W BT Jezus mówi jednak o sobie „Ja”, „Mnie” - z dużej litery. $\mathrm{Z}$ dużej litery mówią też o nim przeciwnicy, co jest jaskrawym zafałszowaniem. Potem redaktorzy pism i książek religijnych zaczęli wymuszać również na autorach artykułów i książek nadużywanie dużych liter w tekstach naukowych i popularnych, przez co publikacje religijne bywają dość niestrawne dla nieprzyzwyczajonych do tej maniery.

\section{Interpretacje teologiczne}

Słowo christos w Ewangeliach generalnie oznacza Mesjasza, namaszczonego, Pomazańca Bożego. Nie jest jeszcze, jak często w listach apostolskich i generalnie w późniejszym chrześcijaństwie, drugim imieniem Jezusa jako Słowa wcie- 
lonego. Na ogół Ewangelie z BT to respektują, ale miejscami tłumacze byli niekonsekwentni, wprowadzając imię „Chrystus” (Mt 1,1.16-18; 11,2; 23,10; Mk $1,1 ; 9,41 ; \mathrm{J} 1,17.41 ; 4,25 ; 17,3)$. W Dziejach Apostolskich jest pół na pół, natomiast w listach zawsze mowa o Chrystusie, co trudno uznać za uzasadnione ${ }^{11}$.

W ważnym tekście, jakim jest odpowiedź Jezusa dana Kajfaszowi, interpretacja teologiczna całkiem wypiera przekład ${ }^{12}$. Kajfasz zapytał - podaję wersję Markową (Mk 14,61): „Czy ty jesteś Mesjaszem, synem Błogosławionego?”. Pierwsze słowa odpowiedzi Jezusa brzmią u Marka: „Ja jestem” (ego eimi: Mk 14,62), a u Mateusza: „Ty powiedziałes” (sy eipas: Mt 26,64). U Łukasza, gdzie ta rozmowa jest bardziej skomplikowana, znajdziemy: „Wy mówicie, że ja jestem" (hymeis legete, hoti ego eimi: Łk 22,70). Historycznie wiarygodniejsza jest oczywiście wersja z Mateusza, Łukasz splata obydwie.

A przekład BT? W Mk 14,62 mamy dosłownie oddane ,ja jestem”, ale u pozostałych tekst jest całkowicie zmieniony. Mt 26,64; Łk 22,70, w oryginale różne, są identycznie przełożone: „Tak, Ja Nim jestem”. Tymczasem oryginalna odpowiedź Jezusa nie zawiera właściwie potwierdzenia. Jezus nie zaprzecza, ale wskazuje oskarżycielom, że to ich zdanie.

Odpowiedź Jezusa Piłatowi została analogicznie zmieniona, żeby nie powiedzieć sfałszowana. Piłat spytał go, czy jest królem żydowskim, „królem Judejczyków” (Łk 23,3). Odpowiedź brzmiała według trzech ewangelistów: „Ty mówisz” (sy legeis: Mt 27,11-14; Mk 15,2; Łk 23,3). To znaczy: „ty sam tak mówisz”, względnie "to ty tak mówisz”. W Biblii Tysiąclecia mamy natomiast znajome: „Tak, Ja Nim jestem” (Mt 27,11-14; Mk 15,2); albo też samo „tak” (Łk 23,3). Raz jeszcze na miejsce dyplomatycznego uniku pojawia się uroczyste, teologiczne potwierdzenie.

Powyżej była mowa o jawnym, świadomym i oczywistym przekręcaniu znaczenia tekstu. Częściej jednak zniekształcenie wynika z powierzchownej lektury i egzegezy.

W zakończeniu Ewangelii Mateuszowej (Mt 28,19), a przedtem i w innych miejscach (Mt 13,39) mowa w przekładach o „końcu świata”. Tymczasem synteleia tou aionos znaczy raczej „dopełnienie się wieków”. Tłumacz preferuje, zapewne bezrefleksyjnie, pewną interpretację, popularną wizję końca świata jako katastrofy. Tymczasem chodzi raczej o dojście do kresu i pełni. Pozytywny aspekt czasów ostatecznych jest w Biblii bardzo znaczący, wbrew tradycjom późniejszym.

11 Nadmienię, że Biblia paulistów, przekład skądinąd dobry merytorycznie i językowo, i w Ewangeliach wzorem Wujka zawsze używa tu słowa „Chrystus”, co często stanowi zgrzyt.

12 Słusznie wytknął to cytowany już ks. E. Dąbrowski, Nowy, 27. 
W tłumaczeniach Ewangelii używane jest powszechnie słowo „duch”. W dzisiejszym języku oznacza ono zasadniczo jakąś istotę duchową, dobrą lub wrogą i złośliwą, to znaczy pewien byt osobowy albo jego emanację. Sens przenośny i bezosobowy, taki jak w zwrocie „wstąpił w niego nowy duch”, pozostaje na marginesie.

Tymczasem w Biblii tak zwany duch (hebr. ruah, gr. pneuma), oznacza najpierw wiatr, a przenośnie siłę podobną do niego, to znaczy niewidzialną. Duch Boży to działanie Boże, duch ludzki to energia i wola w człowieku. W takim razie "duch nieczysty" to też siła: taka, która człowieka czyni nieczystym, zbrukanym, odrywa go od świętości i czystości. „Zły duch”, to siła wroga, która szkodzi. Również tak zwane „demony”, gr. daimonia, rodzaj nijaki, to dość nieokreślone siły ze sfery boskiej.

Same w sobie są to zatem zjawiska nieosobowe. Z relacji Ewangelii przezierają zza nich choroba neurologiczna jak padaczka, choroba psychiczna, moralna degradacja. Mówiąc o tym, ewangeliści po prostu stwierdzają, że z człowiekiem dzieje się coś złego. Może stać za tymi zjawiskami osobowy szatan - aczkolwiek Ewangelie tego nie eksponują. Tylko w midraszowej relacji Mk 5,1-20 duchy nieczyste mają cechy osobowe ${ }^{13}$.

$\mathrm{Na}$ tym tle widać wyraźnie, że tłumacze zakładają koncepcję opętania znaną z apokryfów, jak „Testament Salomona”, oraz z pobożności późniejszej. W koncepcji tej szatan steruje człowiekiem jak pacynką. Byłaby to kwestia z zakresu egzegezy i teologii, gdyby nie to, że skutkiem są deformacje tłumaczeń. Spotkamy w nich często słowo „opętany” i pokrewne. Można by ich używać jako odpowiednika gr. daimonizomenos itd., ale ten czasownik jest względnie rzadki (12 miejsc, wszystkie w Ewangeliach). A BT mówi o opętaniu 24 razy.

W Mk 1,23 mamy do czynienia $\mathrm{z}$ „człowiekiem w duchu nieczystym” (en pneumati akatharto, nawet bez rodzajnika). BT: „człowiek opętany przez ducha nieczystego". Tak samo w Mt 5,2. W Mk 7,25 dziewczynka „miała ducha nieczystego", ale w BT była przez niego „opętana”.

W Łk 8,27 człowiek „mający demony” nazwany został „opętanym przez złe duchy” - zastępowanie „demona” przez „złego ducha” trafia się częściej. W J 7,20 i J 8,48 na miejsce "masz demona” tłumacz wybrał: Jesteś opętany przez złego ducha. Prawie tak samo jest w J 10,20. Zbędne „opętany” powtarza się w J 8,49.52. Również w Dziejach Apostolskich „mający ducha” to w BT „opętani" (Dz 8,7; 16,16; 19,13).

13 Szerzej w mojej książce: M. Wojciechowski, Cuda, 73-104. 


\section{Zaostrzanie i łagodzenie oryginału}

W Biblii Tysiąclecia czytamy: Styszeliście, że powiedziano: Oko za oko i ząb za zab! A ja wam powiadam: Nie stawiajcie oporu złemu (Mt 5,38-39). Tłumacz idzie za Wulgatą i jej przekładami: non resistere malo. Tymczasem greckie antistenai nie oznacza stawiania oporu, lecz przeciwstawianie się z podobną siłą. To znaczy „nie rewanżujcie się złu”, nie odpłacajcie złem za zło. Tłumacz zrobił z zakazu zemsty pacyfistyczny nakaz bierności wobec złoczyńców ${ }^{14}$.

Przesadne przedstawianie nauk Jezusa spotkamy też obok, w zdaniu z Mt 5,27. Biblia Tysiąclecia: Kto pożądliwie patrzy na kobiete, już się w swoim sercu dopuścił z nią cudzołóstwa. Powinno być: Kto przygląda się mężatce, żeby jej pożądać, już popetnit z nia cudzołóstwo w sercu (czyli w myśli).

To samo słowo greckie, gyne, oznacza i kobietę w ogóle, i mężatkę, i tak samo było w językach semickich, ale skoro cudzołóstwo oznacza w Biblii zdradę małżeńską, a nie inne grzechy ze sfery płci, tutaj musi chodzić o kobietę zamężną. Tłumacz poszerzył więc zakaz. Dalej, z planowego przypatrywania się (czasownik blepo) zrobił spojrzenie. Jezus uznał za grzech zamiar cudzołóstwa, a tłumacz samo pragnienie, nawet spontaniczne. Pomylił grzech z pokusą.

W sąsiednim Mt 5,32 dowiadujemy się z Biblii Tysiąclecia, że oddalający żonę naraża ją na cudzołóstwo. Tymczasem Ewangelia mówi: „sprawia, że ona cudzołoży" (poiei auten moicheutenai). Jak widać tłumacz, nie chcąc usprawiedliwiać postępowania porzuconych kobiet, Ewangelię po swojemu poprawił...

Czasami tłumacz osłabiał wzmianki o gniewie czy gwałtownym postępowaniu Jezusa. W Mk 1,43, w perykopie o uzdrowieniu trędowatego, mamy zdanie: „parsknąwszy [embrimesamenos] na niego, zaraz go wyrzucił”, ewentualnie „skarciwszy go, zaraz go wyrzucił”. Biblia Tysiąclecia: Surowo mu przykazał $i$ zaraz go odprawi ${ }^{15}$. Podobny przykład: w Mk 6,45 (Mt 14,22) Jezus „przymusił swoich uczniów”. A w BT: „przynaglił”.

Słowo peirazo/peirasmos jest oddawane dość konsekwentnie przez „kusić” względnie „pokusa”, choć przekład „próba” byłby przeważnie lepszy. Jednakże w J 6,6 Jezus oczywiście nie kusi uczniów, lecz ich wystawia na próbę...

14 Dodajmy, że nakaz nadstawienia drugiego policzka, podany zaraz potem, jest umyślną przesadą, oczywistą przenośnią, która oznacza, że lepiej się narazić na szkodę i krzywdę, niż wdawać w bijatykę. Tak czy inaczej, chodzi tutaj o krzywdy własne: nadstawiania cudzego policzka Jezus nie zalecał!

15 Notabene w tejże perykopie, w Mk 1,41 niektóre świadectwa podają, że Jezus dotknął trędowatego rozgniewawszy się (orgistheis), a nie „zlitowawszy się”. Lekcja trudniejsza jest prawdopodobnie pierwotna, wbrew ogółowi tłumaczy. 


\section{Krytyka tekstu}

Zdarza się przeoczanie trudności z krytyką tekstu. W Mk 1,1 nie zaznaczono nawiasem trójkątnym, co się skądinąd zdarza, niepewnego tekstualnie zwrotu „Syna Bożego”. W J 13,10 należało tak oznaczyć wzmiankę o nogach.

W Mk 3,14-16 sytuacja jest bardziej skomplikowana: opuszczono frazę „których i apostołami nazwał”, natomiast potem zachowano „i ustanowił dwunastu”. Tymczasem ta druga ma w rękopisach słabsze poparcie, a w dodatku występuje raczej w rękopisach już zawierających frazę pierwszą.

Do tej grupy zaliczę zbyt rzadkie akapity. Odrębne myśli bywają łączone w jeden, ale niespójny, tok myślowy (np. Mk 9,49-50: trzy osobne aforyzmy o soli - w dodatku doklejone do odrębnej perykopy o wyłupieniu sobie oka).

\section{Nietrafne słownictwo}

Gdy mówimy o Ewangelii, po polsku kojarzy się to przede wszystkim z książką, w związku z czym w tłumaczeniu należy systematycznie mówić o Dobrej Nowinie lub podobnie, zgodnie z sensem oryginału. Pisana z małej „ewangelia” jest całkowicie niezrozumiała dla zwykłych ludzi. Dotyczy to całego NT.

Tłumacz dodaje zbędne słowa albo i zmienia oryginał. W Mt 14,10 powinno być „ściął Jana” a nie „kazał ściąć”. „Kazać” jest częściej dodawane na zasadzie interpretacji. W Mt 24,51 zakwestionowałbym „każe go surowo ukarać”, czym zastąpiono trafniejsze „każe go ćwiartować” z wydań wcześniejszych (aczkolwiek w oryginale mamy raczej „rozpołowi”).

Gr. epitithemi powinno być tłumaczone systematycznie „nałożyć”, gdyż po polsku położyć rękę można na cudzej własności, a włożyć do kieszeni.

Gr. doma to nie dach, lecz strop czy taras (słowo „powała” jest zbyt staroświeckie).

Synedrion to sanhedryn. Tłumaczenie „Wysoka Rada” jest nieuzasadnione. $\mathrm{W}$ dodatku słowo synedrion czasem oznacza zwykły trybunał (Mt 5,22).

W tymże wersecie more powinno być przełożone „głupcze”, a nie „bezbożniku”, a „Gehenna ognia” nie powinna być nazywana „piekłem ognistym”. Występują w Nowym Testamencie różne obrazy potępienia: Gehenna, ogień, otchłań, ciemności zewnętrzne, śmierć druga, ale nie ma takiego łącznego określenia jak „piekło”.

W Mt 5,5 „na własność posiądą ziemię" jest nietrafne. Powinno być „odziedziczą ziemię". W przypisie można by zaznaczyć, że dziedziczenie uważano w starożytności za najgodniejszy sposób nabycia własności. Tradycyjne „bło- 
gosławieni cisi” jest mylące, gdyż „cisi”, choć to liczba mnoga od „cichy”, w dzisiejszym języku znaczy „potulni, bierni”. Powinno być „łagodni”.

W starożytności używano lampek oliwnych, a nie świec, jak w przekładach polskich. W BT usunięto świece (poza 1 Mch 4,50), ale został świecznik (66 razy), przez co mamy niezręczność w postaci lampy na świeczniku (Mt 5,15).

Analogicznie, nie ma powodu, by pisać o siadaniu do stołu, gdy w oryginale jest zawsze mowa o położeniu się. Przyzwyczailiśmy się, ale jest to adaptacja, która przypomina zastępowanie na Nowej Gwinei, gdzie nie ma owiec, baranka Bożego przez świnkę Bożą.

W Mt 6,1 mowa w oryginale o sprawiedliwości, co w Biblii oznacza moralność, a nie o „uczynkach pobożnych”. Można by tak: „Strzeżcie się, żeby nie postępować moralnie po to, żeby ludzie was widzieli".

W Mt 5,12; 6,2 czytamy o nagrodzie za dobre postępowanie, podczas gdy $\mathrm{w}$ oryginale mamy zapłatę, misthos (notabene w przekładzie Apokalipsy z BT jest poprawnie). Błąd ten wypacza myśl Ewangelii, która stwierdza, że za dobro należy się właśnie zapłata, a nie uznaniowa premia. O stosunkach pieniężnych mowa tu oczywiście przenośnie, ale ten obraz należy oddać prawidłowo.

W Mt 6,22-23 dwa różne słowa greckie przetłumaczono jako „światło”, co zaciera sens.

W Mt 11,16 zwykłych „innych” nazwano bez racji „rówieśnikami”.

W Mt 11,17; 24,40 nie mamy „zawodzić” ani „narzekać”, lecz „bić się” (w piersi).

Trafniejsza byłaby „trocina” (dawniej „źdźbło”) niż „drzazga” w oku (Mt 7,3-5 par.).

W Mt 17,27 występuje „haczyk” a nie „wędka”.

W Mt 19,12 pojawiają się dwa różne zamienniki słowa „eunuch”, oba nietrafne i ze sobą sprzeczne: „niezdatni do małżeństwa” i „bezżenni”. Mogłoby być ewentualnie, ale już konsekwentnie, „niezdolni do małżeństwa”.

W Mt 22,17 par. precyzyjniej byłoby „pogłówne” niż „podatek”. Tamże pojawia się dziwaczne "cezar” z małej litery, choć było to przecież nazwisko panujących.

Z wydania na wydanie słownictwo ulepszano, ale dość mało. Kilka przykładów: krabatos to obecnie „nosze”, a nie „łoże”, chociaż „mata” byłaby lepsza. W J 4,23 poprawiono „chce mieć” na „szuka”. W J 5,31-32 „świadectwo” zastąpiło „sąd”. Opustki, brakujące w dawniejszych wydaniach słowa i zwroty, raczej zostały z czasem uzupełnione. Np. w J 7,42 brakło wcześniej słów „skąd był Dawid".

Niektóre zmiany nie były jednak szczęśliwe. „Pocieszyciela” w Ewangelii Janowej zmieniono na „Parakleta”, choć termin ten jest dla niespecjalistów zupełnie niezrozumiały. 


\section{Inne teksty}

Dla ilustracji podam jeszcze pewne przykłady z innych ksiąg. W Księdze Rodzaju Bóg mówi do Abrahama tak: Pobłogosławię błogosławiących ciebie, a przeklne złorzeczacego tobie (Rdz 12,3). BT podaje natomiast: Będę błogosławił tym, którzy tobie błogosławić będa, a tym, którzy tobie będa złorzeczyli, i ja będę złorzeczyt.

Używa zbyt wielu słów, ale nie w tym rzecz. Oryginał kontrastuje licznych błogosławiących Abrahama i pojedynczego złorzeczącego. W przekładzie pojawia się tu i tam liczba mnoga. Pomyłka ta powtarza się w przekładach polskich, nawet w interlinearnym; w zagranicznych jest praktycznie nieznany. Nasze przekłady sugerują błędnie, że istnieją dwa porównywalne obozy przyjaciół i wrogów, zbawionych i potępionych. Tymczasem błogosławieństwo jest regułą, a przekleństwo wyjątkiem.

W Księdze Wyjścia mowa o przestępstwie spowodowania poronienia przez pobicie (Wj 21,22-23). Dosłownie tak: Jeśli bijąc się mężczyźni uderzyliby kobietę brzemienna, i wyszłoby dziecko jej. A nie będzie nieszczęścia, winny zapłaci grzywnę, którą nałoży mąż kobiety. [...] A jeśli nieszczęście będzie, odda $\dot{z} y c i e$ za życie.

Słowo „nieszczęście” (po hebrajsku 'ason) gdzie indziej w Biblii oznacza w domyśle zgon, śmierć, jak i tutaj (Rdz 42,4 i 38; 44,29). Oznacza to, że jeśli dziecko lub matka umrą, należy się kara śmierci, zgodnie z zasadą odpłaty (niektórzy badacze widzą tu nawet karę śmierci za mniejszą szkodę). Jeśli natomiast wcześniak przeżyje, wystarczy grzywna.

Już w starożytności tłumacze próbowali jednak złagodzić prawa biblijne. Starożytny przekład grecki, Septuaginta, pod wpływem antycznej medycyny zmienia zupełnie sens słowa 'ason. Widzi w nim „formę”, kształty ludzkie. Jeśli dziecko jest „nie uformowane”, karą będzie grzywna. Jeśli zaś „uformowane" (exeikonismenon), winny odda życie za życie. Wulgata, przekład łaciński, odnosi słowo „nieszczęście, zgon” tylko do matki, zapewne pod wpływem komentatorów żydowskich. Za śmierć dziecka poronionego należy się tam grzywna. To zniekształcenie często naśladują, choć bezwiednie, tłumaczenia nowsze, z Biblią Tysiąclecia włącznie, zacierając w ten sposób ważną okoliczność, że dziecko poczęte było w prawie biblijnym chronione przed zabójcą tak jak człowiek dorosły. Notabene konkordancja do BT pokazuje, że tłumacze stosowali do ludzi słowo „płód”, co w tekście oryginalnym nie zachodzi ani razu. 
O zaostrzaniu krytyk wobec Żydów pisałem kiedyś osobno, nie będę tego rozwijał. Te teksty trochę poprawiano, ale nie do końca ${ }^{16}$. Na koniec wspomnę, że problemy pojawiają się także przy innych naszych tłumaczeniach biblijnych. Od niestaranności wpływających na sens nie są wreszcie wolne inne ważne teksty ${ }^{17}$.

Nie podejmuję tu osobnego tematu jakości wstępów i not. Spotyka się w nich jednak liczne stwierdzenia naukowo przestarzałe. Uderza pod tym względem wyższość wydania zatytułowanego Biblia jerozolimska (Poznań 2006), w którym tekst BT (wyd. 5), opatrzono tłumaczeniem objaśnień francuskiej La Bible de Jérusalem w wydaniu z 1996.

Biblia Tysiąclecia, niegdyś praca pionierska, dosyć się zestarzała. Mimo serii rewizji jest obciążona wieloma przeoczeniami i błędami. Stylem się nie wyróżnia. W niektórych miejscach przejawia tendencyjność, która prowadzi do zmiany wymowy tekstów. Takie zmiany typu targumicznego są na tle przekładów współczesnych rażące. Czy należy ją nadal poprawiać? Czy nie lepiej by dokonać nowego tłumaczenia, korzystając ze znacznie zwiększonego przez ubiegłe pięćdziesiąt lat potencjału biblistyki polskiej, jak też z dorobku późniejszych tłumaczeń?

16 M. Wojciechowski, Nowotestamentowe. Pewien rozgłos zyskały przesadne pod tym względem krytyki R. Wekslera-Waszkinela, Błogosławiony, s. 39nn. Omówienie R. Pietkiewicz, Biblia, 165-168.

17 Pierwszy polski przekład dokumentów Soboru Watykańskiego II tłumaczył łaciński termin ministerium jako „urząd”. Tymczasem znaczy on „posługa, posługiwanie” (odpowiednik greckiego diakonia). Tak oto funkcje w Kościele, które według Pisma Świętego i Soboru są służbą, zmieniły się w urzędy... Naprawił to przekład nowszy, z 2002 roku. Interesujący błąd występuje w tłumaczeniu Katechizmu Kościoła Katolickiego (p. 1908). Czytamy tam: Z pewnościa do władzy należy rozstrzyganie - $w$ imię dobra wspólnego między różnymi partykularnymi interesami. Powinna ona jednak zapewnić każdemu to, czego potrzebuje on do prowadzenia życia prawdziwie ludzkiego: wyżywienie, odzież, opiekę zdrowotna, prace, wychowanie i kulture, odpowiednia informacje, prawo do założenia rodziny. Tymczasem w oficjalnej wersji łacińskiej nie ma „zapewnić”, lecz „uczynić dostępnym” (accessibile reddere). Kościół chce, by władza zapewniła warunki do uzyskania potrzebnych dla godnego życia dóbr, a tłumacz, rzecznik państwa opiekuńczego, żąda, by władze te dobra dostarczyły. 


\section{Bibliografia}

Chmiel J., Textus Receptus współczesnej Biblii polskiej. O trzecim wydaniu Biblii Tysiąclecia, Ruch Biblijny i Liturgiczny 34 (1981) 5, s. 274-280.

Dąbek T.M., Śp. o. prof. dr hab. Augustyn Jankowski OSB i Biblia Tysiąclecia, Ruch Biblijny i Liturgiczny 59 (2006) 3, s. 235-239.

Dąbrowski E., Nowy polski przekład Pisma Świętego z języków oryginalnych. Krytyczna ocena tzw. Biblii Tysiąclecia, Londyn 1967.

Dziadosz D., Biblia Tysiaclecia jako wydarzenie religijne i świadectwo pracy polskich biblistów, Zeszyty Naukowe KUL 49 (2006) 2, 3-18.

Felski W., Czy tylko Biblia Tysiąclecia? Inne propozycje translatologiczne, Studia Pelplińskie 39 (2008), s. 307-319.

Frankowski J., Biblia Tysiąclecia - jej wartość i znaczenie (konfrontacja z ocena ks. E. Dąbrowskiego), Ruch Biblijny i Liturgiczny 33 (1970) 2-3, s. 76-87.

Frankowski J., Biblia Tysiąclecia i problematyka dzisiejszych polskich przekładów Pisma Świętego, Znak (1975) $6=$ nr 252, s. 709-737.

Frankowski J.. Dlaczego trzeba było dokonać nowego przekładu Biblii, Znak (1974)1 = $=$ nr 235, s. 63-82.

Jankowski A., Z problematyki współczesnego przekładu Pisma Świętego, Studia Gnesnensia 1 (1975), s. 321-331.

Kotecki D., Biblia polska, Studia Nauk Teologicznych PAN 4 (2009), s. 201-222.

Matuszczyk B., Biblia Tysiaclecia wobec tradycji Wujkowego przekładu Pisma Świętego, w: Inspiracje chrześcijańskie w kulturze Europy. Materiały z konferencji 11-14 maja 1999 r., red. Ewa Woźniak [Cz. 1], Łódź 2000, s. 201-210.

Mędala S., Biblia Tysiąclecia. Kilka uwag na temat tłumaczenia, Collectanea Theologica 37 (1967)2, s. 82-96.

Penar T., O nowa Biblię Tysiąclecia, Przemiany 1968, s. 422-428.

Pietkiewicz R., Biblia Tysiąclecia $w$ tradycji polskiego edytorstwa biblijnego, diss. PWT Wrocław 2004 (PDF, wolny dostęp): http://digital.fides.org.pl/dlibra/aresults?action=SearchAction \&QI=C53007296242CFAF1EE7348F8A4877DE-1

Schnayder J., Z problematyki przekładu biblijnego. Uwagi filologa na marginesie Biblii Tynieckiej, Ruch Biblijny i Liturgiczny (1971) 4-5, s. 161-187.

Szczypińska B., Ewangelie tylekroć tłumaczone...: studia o przekładach i przekładaniu, Gdańsk 2005.

Warzecha J., Kilka uwag o piątym wydaniu Biblii Tysiąclecia, Collectanea Theologica 71 (2001)1, s. 113-123.

Weksler-Waszkinel R.J., Błogosławiony Bóg Izraela, Towarzystwo Naukowe KUL. Prace Wydziału Filologicznego 84, Lublin 2000 (o BT zob. s. 39nn).

Wojciechowski M., Cuda Jezusa, Częstochowa 2010.

Wojciechowski M., Nowotestamentowe teksty o Żydach w nowszych polskich przekładach biblijnych, Collectanea Theologica 53 (1993)2, s. 79-88.

Wojciechowski M., Szkodliwe błędy tłumaczy Biblii, Idziemy 2011, nr 37, s. 38-39. 